\title{
Pengaruh Faktor Internal dan Faktor Eksternal Perusahaan Pada Kecepatan Publikasi Laporan Keuangan
}

\author{
Ni Ketut Ressa Mahayani ${ }^{1}$ \\ Made Gede Wirakusuma ${ }^{2}$ \\ ${ }^{1,2}$ Fakultas Ekonomi dan Bisnis Universitas Udayana (Unud), Bali, Indonesia \\ e-mail: ressamahayani@yahoo.com
}

\begin{abstract}
ABSTRAK
Penelitian ini dilakukan pada perusahaan sektor industri barang konsumsi yang terdaftar di Bursa Efek Indonesia pada periode 2014-2017. Sampel yang diperoleh sejumlah 16 perusahaan dengan 64 amatan. Profitabilitas berpengaruh positif pada kecepatan publikasi laporan keuangan. Hal ini menunjukkan bahwa semakin tinggi profitabilitas maka semakin cepat perusahaan mempublikasikan laporan keuangannya. Kompleksitas operasi perusahaan berpengaruh negatif pada kecepatan publikasi laporan keuangan. Hal ini menunjukkan bahwa semakin kompleks operasi perusahaan dapat memperlambat publikasi laporan keuangannya. Audit tenure dan reputasi KAP tidak berpengaruh pada kecepatan publikasi laporan keuangan. Hal ini menunjukkan bahwa audit tenure yang panjang atau pendek dan KAP yang memiliki reputasi atau tidak bereputasi tidak berpengaruh pada kecepatan publikasi laporan keuangan.

Kata kunci: Profitabilitas, kompleksitas operasi perusahaan, audit tenure, reputasi KAP, kecepatan publikasi laporan keuangan
\end{abstract}

\begin{abstract}
This research was conducted on consumer goods industry sector companies listed on the Indonesia Stock Exchange in the 2014-2017 period. Samples obtained by 16 companies with 64 observations. Profitability has a positive effect on the speed of publication of financial statements. This shows that the higher the profitability, the faster the company publishes its financial statements. The complexity of the company's operations has a negative effect on the speed of financial statement publication. This shows that the more complex the company's operations can slow the publication of its financial statements. The audit tenure and reputation of KAP have no effect on the speed of publication of financial statements. This indicates that a long or short audit tenure and reputable or non-reputable KAP have no effect on the speed of publication of financial statements.
\end{abstract}

Keywords: Profitability, complexity of company operations, audit tenure, reputation of KAP, speed of publication of financial statements

\section{PENDAHULUAN}

Laporan keuangan merupakan alat bagi pihak internal dan pihak eksternal untuk mengetahui kondisi keuangan dan kinerja dari suatu perusahaan yang digunakan sebagai pedoman untuk pengambilan keputusan. Laporan keuangan menyediakan informasi tentang sumber daya ekonomi entitas pelapor, klaim terhadap entitas 
Ni Ketut Ressa Mahayani dan Made Gede Wirakusuma. Pengaruh ...

pelapor, dampak dari transaksi dan peristiwa serta kondisi lainnya yang mengubah sumber daya dan klaim tersebut (IAI, 2017). Karakteristik kualitatif dari informasi akuntansi yang harus terkandung di dalam laporan keuangan menurut Statement of Financial Accounting Concept (SFAC) No. 2 adalah relevansi (relevance), keandalan informasi (reliable), dan daya banding (comparability).

Ketepatan waktu merupakan karakteristik intrinsik dari pelaporan keuangan dan elemen penting dari relevansi informasi (Clatworthy \& Peel, 2016). Perusahaan yang menyajikan laporan keuangannya secara tepat waktu kepada publik akan menambah nilai manfaat yang terkandung di dalam laporan keuangan tersebut terhadap pengambilan keputusan yang dilakukan. Ketepatan waktu mengisyaratkan perusahaan untuk mempublikasikan laporan keuangannya dengan cepat, sehingga semakin cepat laporan keuangan disajikan kepada publik akan semakin baik penilaian masyarakat kepada perusahaan tersebut.

Kecepatan publikasi yang dilakukan oleh perusahaan mendorong kecepatan keputusan yang dapat diambil oleh pihak-pihak yang berkepentingan. Kecepatan perusahaan dalam mempublikasi laporan keuangannya merupakan sinyal baik dan menguntungkan bagi pihak yang berkepentingan sehingga menciptakan respon yang positif, sedangkan perusahaan yang terlambat dalam menyampaikan laporan keuangannya akan menimbulkan respon negatif.

Kecepatan suatu perusahaan dalam mempublikasikan laporan keuangannya dapat dipengaruhi oleh banyak faktor, baik itu faktor internal ataupun faktor eksternal. Penelitian ini berfokus pada dua faktor internal 
perusahaan yaitu profitabilitas dan kompleksitas operasi perusahaan dan dua faktor eksternal perusahaan yaitu audit tenure dan reputasi KAP.

Profitabilitas merupakan salah satu faktor internal perusahaan yang sering dihubungkan dengan kecepatan publikasi laporan keuangan. Profitabilitas adalah rasio keuangan yang biasanya digunakan untuk menggambarkan kemampuan suatu perusahaan dalam menghasilkan keuntungan (laba) memakai seluruh modal yang dimiliki perusahaan. Para manajer cenderung untuk cepat melaporkan laporan keuangannya apabila mereka memiliki good news (laba) dibandingkan apabila mereka memiliki bad news karena akan berpengaruh pada harga saham (Adebayo \& Adebiyi, 2016). Hasil tersebut didukung dengan penelitian Budiadnyani \& Ratnadi (2015) dan Rambe et al. (2017) mendapatkan hasil bahwa profitabilitas berpengaruh pada kecepatan publikasi laporan keuangan. Hasil berbeda ditemukan oleh penelitian Mardyana (2014) dan Devi \& Suaryana (2016) yang menyatakan bahwa profitabilitas tidak mempengaruhi keterlambatan publikasi laporan keuangan.

Tingkat kompleksitas operasi perusahaan bergantung pada jumlah dan lokasi unit operasi (cabang), ada tidaknya perusahaan anak, serta diversifikasi jalur produk dan pasar. Pradana (2013) menjelaskan bahwa perusahaan membutuhkan waktu yang lama dalam mempublikasikan laporan keuangannya karena kompleksnya perusahaan. Penelitian Widyastuti \& Astika (2017) dan Rusmin \& Evans (2017) yang menyatakan bahwa kompleksitas operasi perusahaan berpengaruh positif terhadap audit delay, berarti apabila perusahaan memiliki banyak anak perusahaan akan memperlambat publikasi laporan 
Ni Ketut Ressa Mahayani dan Made Gede Wirakusuma. Pengaruh ...

keuangan. Hasil berbeda ditemukan oleh penelitian Darmirai \& Ulupui (2014) dan Panjaitan et al. (2013) yang dimana menemukan bahwa kompleksitas operasi perusahaan tidak memiliki pengaruh pada ketepatwaktuan pelaporan keuangan.

Audit tenure atau masa perikatan audit adalah lama hubungan kerja diantara auditor dengan klien dalam pemeriksaan laporan keuangan (Anggreni \& Latrini, 2016). Audit yang efisien dapat tercipta dari lamanya perusahaan melakukan perikatan dengan kantor akuntan publik, sehingga perusahaan dalam mempublikasikan laporan keuangan akan semakin cepat. Menurut Van Johnson (2002) kualitas audit lebih tinggi diberikan di saat masa kerja auditor lebih lama. Menurut Anggreni \& Latrini (2016) menyatakan bahwa semakin lama perikatan klien dengan auditor yang sama menyebabkan kecepatan publikasi laporan keuangan meningkat atau cenderung cepat. Hasil yang berbeda ditemukan oleh penelitian Krisnanda \& Ratnadi (2017) dan Narayana \& Yadnyana (2017) yang menyatakan bahwa audit tenure tidak memiliki pengaruh pada kecepatan publikasi laporan keuangan tahunan.

Reputasi kantor akuntan publik sering dihubungkan dengan kualitas audit yang dihasilkan. Menggunakan KAP yang memiliki reputasi baik adalah penting untuk mendapatkan kualitas audit yang tinggi (Skinner \& Srinivasan, 2012). Reputasi KAP dapat diukur dengan menggunakan ukuran KAP itu sendiri, apakah KAP tersebut termasuk ke dalam kelompok KAP big four ataupun non-big four. Darmansyah \& Suratno (2018) menyatakan banyaknya kasus kecurangan laporan keuangan yang melibatkan auditor independen big four menimbulkan keraguan mengenai kualitas dari hasil audit, sehingga dalam penelitian ini digunakan 
spesialisasi industri auditor untuk mengukur reputasi KAP. Menurut Senjaya \& Suprasto H (2016), Primantara \& Rasmini (2015), dan Sawitri \& Budiartha (2018) menyatakan spesialisasi industri seorang auditor dapat membantu untuk menemukan kesalahan yang terjadi dalam laporan keuangan klien lebih cepat karena mereka mengetahui lebih banyak mengenai industri kliennya sehingga dapat memperpendek audit delay. Hasil yang berbeda ditemukan oleh penelitian Rustiarini \& Sugiarti (2013) yang menyatakan bahwa spesialisasi industri auditor tidak berpengaruh pada ketepatwaktuan publikasi laporan keuangan.

Teori keagenan merupakan teori yang menjelaskan hubungan antara agen sebagai pihak yang mengelola perusahaan dan prinsipal sebagai pihak pemilik yang keduanya terikat dalam sebuah kontrak (Pradipta \& Suryono, 2017). Hubungan keagenan dapat menimbulkan suatu konflik yang dipengaruhi oleh perbedaan informasi (asimetri informasi) yang dimiliki pihak agen dengan pihak prinsipal. Pelaporan keuangan memainkan peran penting dalam mengurangi asimetri informasi yang ada antara manajer dengan komisaris independen dan pemegang saham (Armstrong et al., 2010). Publikasi laporan keuangan yang disampaikan dengan cepat akan mengurangi kecurangan oleh pihak agen sebagai pihak yang memiliki informasi lebih banyak dibandingkan dengan pihak prinsipal. Kecepatan publikasi yang dilakukan oleh perusahaan dapat terjadi karena tingginya profitabilitas yang dimiliki perusahaan sesuai dengan bonus plan hypothesis. Kompleksnya operasi perusahaan dapat memperlambat publikasi laporan keuangan. Kompleksitas operasi juga dapat mempertinggi resiko asimetri informasi. Perikatan antara perusahaan dengan kantor akuntan publik dapat 
Ni Ketut Ressa Mahayani dan Made Gede Wirakusuma. Pengaruh ...

mempersingkat waktu pengerjaan audit karena dapat meningkatkan fungsi kontrol. Kualitas laporan keuangan dapat meningkat apabila menggunakan kantor akuntan publik yang memiliki reputasi yang baik, sehingga dapat meminimalisir terjadinya asimetri informasi.

Penelitian ini berfokus pada perusahaan sektor industri barang konsumsi, karena sektor tersebut merupakan sektor yang paling diminati oleh penanam modal dalam negeri (PMDN) terutama industri makanan sebesar Rp 38,5 triliun atau $14,7 \%$ dari total investasi sebesar Rp 82,1 triliun sepanjang tahun 2017, sedangkan untuk penanam modal asing (PMA) yang berinvestasi pada sektor industri barang konsumsi lebih berminat berinvestasi di industri kimia dan farmasi sebesar US\$ 2,6 miliar atau 8\% dari total investasi sepanjang tahun 2017 (www.cnbcindonesia.com, 30 Januari 2018).

Kecepatan publikasi laporan keuangan tahunan setiap perusahaan berbedabeda. Pada tahun 2017 perusahaan yang mempublikasikan laporan keuangan tahunannya paling cepat adalah HMSP dan UNVR dengan rentang waktu publikasi adalah 0 hari dari tanggal penandatanganan laporan audit. Perusahaan yang paling lambat mempublikasikan laporan keuangannya adalah BTEK dimana rentang waktu publikasi adalah 63 hari dari tanggal penandatangan laporan audit.

Perbedaan penelitian mengenai ketepatan waktu dengan kecepatan publikasi laporan keuangan yaitu apabila ketepatan waktu lebih berbasis pada regulasi sedangkan kecepatan publikasi laporan keuangan lebih menekankan pada sisi waktu yaitu cepat tidaknya perusahaan mempublikasikan laporan keuangannya setelah penandatangan laporan auditan. Pentingnya kecepatan 
publikasi laporan keuangan untuk membantu pihak-pihak yang berkepentingan dalam membuat keputusan dengan cepat dan masih banyaknya ketidakkonsistenan hasil penelitian yang didapatkan oleh peneliti terdahulu mengenai profitabilitas, kompleksitas operasi perusahaan, audit tenure, dan reputasi KAP yang mempengaruhi kecepatan publikasi laporan keuangan.

Penelitian ini bertujuan untuk memperoleh bukti pengaruh profitabilitas, kompleksitas operasi perusahaan, audit tenure, dan reputasi KAP pada kecepatan publikasi laporan keuangan. Kontribusi hasil penelitian ini dapat memberikan tambahan bukti empiris mengenai teori keagenan (agency theory) bahwa kecepatan publikasi laporan keuangan dapat dipengaruhi oleh profitabilitas, kompleksitas operasi perusahaan, sedangkan audit tenure, dan reputasi KAP tidak berpengaruh pada kecepatan publikasi laporan keuangan. Penelitian ini juga dapat dijadikan refrensi informasi sebagai bahan pertimbangan pengambilan keputusan bagi pihak-pihak yang berkepentingan seperti investor dan perusahaan.

Profitabilitas adalah rasio keuangan yang biasanya digunakan untuk menggambarkan kemampuan suatu perusahaan dalam menghasilkan keuntungan (laba) memakai seluruh modal yang dimiliki perusahaan. Vuran \& Adiloglu (2013) berpendapat bahwa ketepatan waktu memiliki hubungan dengan profitabilitas dengan variabel Return On Asset (ROA) dalam teori keagenan (agency theory) melalui bonus plan hypothesis. Perusahaan yang memperoleh laba cenderung tepat waktu menyampaikan laporan keuangannya dan sebaliknya apabila mengalami kerugian (Dyer \& Mc Hugh, 1975). Semakin besar rasio profitabilitas maka semakin baik pula kinerja perusahaan dalam menghasilkan 
Ni Ketut Ressa Mahayani dan Made Gede Wirakusuma. Pengaruh ...

laba, sehingga perusahaan akan cenderung untuk memberikan informasi tersebut kepada pihak lain yang berkepentingan dengan lebih cepat (Rambe et al., 2017).

Budiadnyani \& Ratnadi (2015) mendapatkan hasil bahwa profitabilitas berpengaruh pada kecepatan publikasi laporan keuangan. Hasil tersebut didukung dengan penelitian Laksono \& Mu'id (2014) dan Rusmin \& Evans (2017) yang menyatakan bahwa semakin tinggi profitabilitas maka berpengaruh pada ketepatwaktuan perusahaan dalam mempublikasikan laporan keuangannya menjadi semakin cepat. Berdasarkan uraian di atas, maka hipotesis yang dapat disusun adalah sebagai berikut.

$\mathrm{H}_{1}$ : Profitabilitas berpengaruh positif pada kecepatan publikasi laporan keuangan.

Tingkat kompleksitas operasi suatu perusahaan sangat tergantung pada kuantitas dan perusahaan anak serta keanekaragaman produk dan pasarnya. Kompleksitas operasi perusahaan mendorong terjadinya asimetri informasi yang lebih besar (Liu \& Lai, 2012). Organisasi dengan berbagai jenis atau jumlah pekerjaan dan audit menimbulkan masalah manajerial dan organisasi yang lebih rumit karena terjadi ketergantungan yang semakin kompleks (Darmawan \& Widhiyani, 2017). Widyastuti \& Astika (2017) menemukan bahwa kompleksitas operasi perusahaan memiliki hubungan positif dengan audit delay, yang berarti semakin tinggi kompleksitas operasi perusahaan akan memperlambat publikasi laporan keuangan. Hasil tersebut didukung dengan penelitian Pradana (2013), Widyastuti \& Astika (2017), dan Rusmin \& Evans (2017) menyatakan semakin kompleks operasi suatu perusahaan maka akan semakin panjang waktu penyelesaian audit, sehingga berdampak pada semakin lambat perusahaan dalam 
mempublikasikan laporan keuangannya. Berdasarkan uraian di atas, maka hipotesis yang dapat disusun adalah sebagai berikut.

$\mathrm{H}_{2}$ : Kompleksitas operasi perusahaan berpengaruh negatif pada kecepatan publikasi laporan keuangan.

Audit tenure atau masa perikatan audit adalah lama hubungan kerja diantara auditor dengan klien dalam pemeriksaan laporan keuangan (Anggreni \& Latrini, 2016). Perikatan antara kantor akuntan publik dan perusahaan dapat meningkatkan fungsi kontrol yang dapat membantu prinsipal dalam mengawasi prilaku agen. Penelitian yang dilakukan oleh Van Johnson (2002) menunjukkan bahwa kecurangan keuangan lebih mungkin terjadi pada tahun-tahun awal hubungan auditor dengan klien dan menunjukkan bahwa masa perikatan auditor yang panjang tidak mempengaruhi kecurangan keuangan. Lee et al. (2009) menyatakan semakin lama suatu perusahaan menjadi klien dari KAP maka semakin singkat audit delay. Semakin lama audit tenure maka memungkinkan auditor untuk mengenali perusahaan sehingga mempercepat waktu penyelesaian audit laporan keuangan. Anggreni \& Latrini (2016) menyatakan adanya pengaruh positif antara audit tenure dengan jangka waktu penyelesaian audit, sehingga mempercepat publikasi laporan keuangan auditan. Berdasarkan uraian di atas, maka hipotesis yang dapat disusun adalah sebagai berikut.

$\mathrm{H}_{3}$ : Audit tenure berpengaruh positif pada kecepatan publikasi laporan keuangan.

Reputasi KAP dipandang penting dewasa ini, perusahaan yang menggunakan auditor yang memiliki reputasi yang baik dianggap memberikan kualitas audit yang lebih baik dibandingkan dengan KAP yang tidak memiliki 
Ni Ketut Ressa Mahayani dan Made Gede Wirakusuma. Pengaruh ...

reputasi karena dianggap dapat meminimalisir terjadinya asimetri informasi. KAP yang memiliki reputasi akan mempercepat publikasi laporan keuangan karena hal tersebut merupakan cara mereka untuk mempertahankan reputasi mereka. Reputasi auditor sering dihubungkan dengan kualitas audit yang dilakukan. Kualitas audit yang baik dapat dihasilkan dengan menggunakan auditor yang memiliki spesialisasi industri.

Primantara \& Rasmini (2015), Senjaya \& Suprasto H (2016), dan Dhao \& Pham (2014) menyatakan bahwa auditor spesialis industri diyakini memiliki kemampuan untuk mendeteksi kesalahan-kesalahan secara lebih baik, meningkatkan efisiensi dan pengetahuan tentang kejujuran laporan keuangan, sehingga perusahaan yang di audit oleh auditor yang memiliki spesialisasi industri dapat membuat audit delay menjadi lebih pendek, sehingga publikasi laporan keuangan dapat dilakukan dengan cepat. Hossien \& Zohreh (2013) menunjukkan bahwa audit report lag lebih pendek pada perusahaan yang diaudit oleh audit spesialisasi industri. Berdasarkan uraian di atas, maka hipotesis yang dapat disusun adalah sebagai berikut.

$\mathrm{H}_{4}$ : Reputasi KAP berpengaruh positif pada kecepatan publikasi laporan keuangan.

\section{METODE PENELITIAN}

Penelitian ini dilakukan di Indonesia dengan menganalisis perusahaan-perusahaan yang terdaftar di Bursa Efek Indonesia (BEI) tahun 2014-2017 dan telah menyediakan laporan keuangan tahunan yang dapat diakses melalui website www.idx.co.id. Alasan peneliti memilih lokasi penelitian di Bursa Efek Indonesia 
adalah karena tersedianya seluruh data dari obyek penelitian yang lengkap mengenai perusahaan yang telah go public pada website www.idx.co.id. Variabel terikat dalam penelitian ini adalah kecepatan publikasi laporan keuangan. Variabel bebas yang digunakan dalam penelitian ini adalah profitabilitas, kompleksitas operasi perusahaan, audit tenure, dan reputasi KAP.

Krisnanda \& Ratnadi (2017) menyatakan kecepatan publikasi dapat diukur dengan menghitung rentang (selisih) hari dari tanggal laporan auditan sampai dengan tanggal publikasi.

Profitabilitas diukur menggunakan rumus (Rambe et al., 2017), yaitu:

$$
\text { ROA }=\frac{\text { Laba Bersih Setelah Pajak }}{\text { Total Aset }} \times 100 \%
$$

Penilaian kompleksitas operasi perusahaan diukur menggunakan dummy, untuk perusahaan yang tidak melaporkan laporan keuangan konsolidasian diberi kode 0 , sedangkan perusahaan yang melaporkan laporan keuangan konsolidasian diberi kode 1 (Panjaitan et al., 2013).

Penilaian audit tenure diukur menggunakan dummy, untuk perusahaan yang melakukan perikatan dengan auditor selama satu tahun diberi kode 0 , sedangkan perusahaan yang melakukan perikatan dengan auditor lebih dari satu tahun diberi kode 1 (Panjaitan et al., 2013).

Pengukuran KAP spesialis industri pada penelitian ini mengikuti penelitian Primantara \& Rasmini (2015) dan Sawitri \& Budiartha (2018) yang menyatakan bahwa KAP yang dianggap memiliki spesialisasi adalah KAP yang memiliki klien $15 \%$ dari total perusahaan dalam kelompok industrinya. Penilaian KAP spesialis industri diukur menggunakan dummy, untuk perusahaan yang tidak 
Ni Ketut Ressa Mahayani dan Made Gede Wirakusuma. Pengaruh ...

menggunakan KAP spesialis industri diberi kode 0, sedangkan menggunakan KAP spesialis industri diberi kode 1.

Populasi dari penelitian ini adalah 47 perusahaan sektor industri barang konsumsi yang terdaftar di Bursa Efek Indonesia (BEI) tahun 2014-2017. Perusahaan sektor industri konsumsi dipilih karena pertimbangan homogenitas dalam aktivitas produksinya dan sektor ini adalah sektor yang paling diminati oleh investor serta memiliki peluang untuk terus berkembang. Sampel akan diambil dari populasi tersebut berdasarkan pendekatan non-probability sampling menggunakan teknik purposive sampling.

Data dikumpulkan dengan cara mencatat, mengamati, serta mempelajari buku-buku, karya ilmiah berupa skripsi, jurnal akuntansi, catatan-catatan, dan situs internet yang relevan serta sesuai dengan penelitian, diantaranya www.idx.co.id.

Regresi linier berganda bertujuan untuk menguji pengaruh profitabilitas, kompleksitas operasi perusahaan, audit tenure, dan reputasi KAP pada kecepatan publikasi laporan keuangan. Analisis linear berganda dilakukan dengan dibantu program Statisstical Package for Social Science (SPSS) dengan tingkat signifikansi 5 persen. Model analisis regresi linear berganda dalam penelitian ini dirumuskan sebagai berikut.

$Y=\alpha+\beta_{1} \cdot X_{1}+\beta_{2} \cdot X_{2}+\beta_{3} \cdot X_{3}+\beta_{4} \cdot X_{4}+\varepsilon$

Keterangan:

$\mathrm{Y}=$ kecepatan publikasi laporan keuangan

$\alpha=$ nilai konstanta

$\beta_{1}=$ koefisien regresi profitabilitas

$\beta_{2}=$ koefisien regresi kompleksitas operasi perusahaan

$\beta_{3}=$ keofisien regresi audit tenure 
$\beta_{4}=$ koefisien regresi reputasi KAP

$\mathrm{X}_{1}=$ profitabilitas

$\mathrm{X}_{2}=$ kompleksitas operasi perusahaan

$\mathrm{X}_{3}=$ audit tenure

$\mathrm{X}_{4}=$ reputasi KAP

$\varepsilon=$ standar error

\section{HASIL DAN PEMBAHASAN}

Statistik deskriptif dalam penelitian ini digunakan untuk menjelaskan variabelvariabel yang diteliti yaitu kecepatan publikasi laporan keuangan, profitabilitas, kompleksitas operasi perusahaan, audit tenure, dan reputasi KAP. Hasil uji statistik deskriptif pada penelitian ini disajikan pada Tabel 1 sebagai berikut.

Tabel 1.

Hasil Uji Statistik Deskriptif

\begin{tabular}{lrrrrr}
\hline & N & \multicolumn{1}{c}{ Minimum } & Maximum & \multicolumn{1}{c}{ Mean } & Std. Deviation \\
\hline Kecepatan Publikasi & 64 & 1,00 & 38,00 & 13,75 & 9,352 \\
Profitabilitas & 64 & $-9,71$ & 26,15 & 8,1695 & 5,47493 \\
Kompleksitas Operasi & 64 & 0,00 & 1,00 & 0,69 & 0,467 \\
Perusahaan & & & & & \\
Audit Tenure & 64 & 0,00 & 1,00 & 0,33 & 0,473 \\
Reputasi KAP & 64 & 0,00 & 1,00 & 0,34 & 0,479 \\
Valid N (listwise) & 64 & & & & \\
\hline
\end{tabular}

Sumber: Data Diolah, 2018

Tabel 1 di atas menunjukkan hasil statistik deskriptif dari masing-masing variabel penelitian bahwa variabel kecepatan publikasi (Y) memiliki nilai terendah (minimum) sebesar 1,00 dan nilai tertinggi (maximum) sebesar 38,00. Hal ini berarti perusahaan sektor industri barang konsumsi paling cepat mempublikasikan laporan keuangannya 1 hari dan paling lama 38 hari setelah dilakukannya penandatanganan laporan audit independen. Nilai rata-rata (mean) kecepatan publikasi sebesar 13,75 dengan penyimpangan nilai rata-ratanya yang ditunjukkan melalui standar deviasi sebesar 9,352 menunjukkan bahwa kecepatan 
Ni Ketut Ressa Mahayani dan Made Gede Wirakusuma. Pengaruh ...

rata-rata publikasi laporan keuangan auditan sektor industri barang konsumsi sebesar 13,75 hari.

Profitabilitas $\left(\mathrm{X}_{1}\right)$ memiliki nilai terendah (minimum) sebesar $-9,71$ dan nilai tertinggi (maximum) profitabilitas sebesar 26,15. Hal ini berarti dilihat dari kemampuan perusahaan sektor industri barang konsumsi untuk memperoleh laba paling rendah sebesar $-9,71$ dan paling tinggi sebesar 26,15 . Nilai rata-rata (mean) profitabilitas sebesar 8,1695 dengan penyimpangan nilai rata-ratanya yang ditunjukkan melalui standar deviasi sebesar 5,47493 menunjukkan bahwa ratarata kemampuan perusahaan untuk memperoleh laba sebesar 8,1695.

Kompleksitas operasi perusahaan $\left(\mathrm{X}_{2}\right)$ mempunyai nilai terendah (minimum) sebesar 0,00 berarti perusahaan tidak memiliki anak perusahaan dan nilai tertinggi (maximum) kompleksitas operasi perusahaan sebesar 1,00 berarti perusahaan memiliki anak perusahaan. Nilai rata-rata (mean) kompleksitas operasi perusahaan yaitu sebesar 0,69 dengan penyimpangan nilai rata-ratanya yang ditunjukkan melalui standar deviasi sebesar 0,467 menunjukkan perusahaan sektor industri barang konsumsi yang menjadi sampel dalam penelitian yang memiliki anak perusahaan sebesar $69 \%$.

Audit Tenure $\left(\mathrm{X}_{3}\right)$ mempunyai nilai terendah (minimum) sebesar 0,00 berarti perusahaan melakukan perikatan selama 1 tahun dan nilai tertinggi (maximum) audit tenure sebesar 1,00 berarti perusahaan melakukan perikatan lebih dari 1 tahun. Nilai rata-rata (mean) audit tenure yaitu sebesar 0,33 dengan penyimpangan nilai rata-ratanya yang ditunjukkan melalui standar deviasi sebesar 0,473 menunjukkan perusahaan sektor industri barang konsumsi yang menjadi 
sampel dalam penelitian yang melakukan perikatan antara auditor dan perusahaan klien lebih dari 1 tahun sebesar 33\%.

Reputasi KAP $\left(\mathrm{X}_{4}\right)$ mempunyai nilai terendah (minimum) 0,00 berarti perusahaan tidak menggunakan KAP yang memiliki spesialisasi industri dan nilai tertinggi (maximum) reputasi KAP sebesar 1,00 berarti perusahaan menggunakan KAP yang memiliki spesialisasi industri. Nilai rata-rata (mean) reputasi KAP yaitu sebesar 0,34 dengan penyimpangan nilai rata-ratanya yang ditunjukkan melalui standar deviasi sebesar 0,479 menunjukkan perusahaan sektor industri barang konsumsi yang menjadi sampel penelitian menggunakan KAP yang memiliki spesialisasi industri sebesar $34 \%$.

Uji normalitas menunjukkan hasil sebesar 0,491 > 0,05 yang berarti model regresi berdistribusi normal. Uji autokorelasi menunjukkan hasil sebesar 1,7303 < $1,780<2,2697$ yang berarti model regresi tidak menunjukkan gejala autokorelasi. Uji multikolinearitas menunjukkan hasil nilai tolerance semua variabel bebas lebih besar dari 0,1 (10\%) yang berarti model regresi tidak terjadi multikolinearitas. Uji heteroskedastisitas menunjukkan hasil nilai signifikansi semua variabel bebas lebih besar dari 0,05 yang berarti model regresi tidak mengalami heteroskedastisitas. Hasil uji asumsi klasik menunjukkan bahwa model regresi dapat diterima untuk dilakukan analisis tahap selanjutnya.

Regresi linier berganda bertujuan untuk menguji pengaruh profitabilitas, kompleksitas operasi perusahaan, audit tenure, dan reputasi KAP pada kecepatan publikasi laporan keuangan. Tabel 2 berikut menampilkan hasil regresi linear berganda. 
Tabel 2.

Hasil Regresi Linear Berganda

\begin{tabular}{|c|c|c|c|c|c|c|c|}
\hline \multirow[b]{2}{*}{ Model } & \multicolumn{2}{|c|}{$\begin{array}{c}\text { Unstandardized } \\
\text { Coefficients }\end{array}$} & \multirow{2}{*}{$\begin{array}{l}\text { Standardize } \\
\text { Coefficients } \\
\text { Beta }\end{array}$} & \multirow[b]{2}{*}{$T$} & \multirow[b]{2}{*}{ Sig. } & \multicolumn{2}{|c|}{$\begin{array}{l}\text { Collinearity } \\
\text { Statistics }\end{array}$} \\
\hline & $B$ & Std. Error & & & & Tolerance & $V I F$ \\
\hline 1 (Constant) & 18,659 & 2,433 & & 7,668 & 0,000 & & \\
\hline Profitabilitas & 0,464 & 0,222 & 0,272 & 2,090 & 0,041 & 0,771 & 1,296 \\
\hline Kompleksitas & $-10,150$ & 2,562 & $-0,507$ & $-3,962$ & 0,000 & 0,796 & 1,256 \\
\hline Operasi & & & & & & & \\
\hline Perusahaan & & & & & & & \\
\hline Audit Tenure & $-3,518$ & 2,289 & $-0,178$ & $-1,537$ & 0,130 & 0,972 & 1,028 \\
\hline Reputasi KAP & $-1,657$ & 2,347 & $-0,085$ & $-0,706$ & 0,483 & 0,904 & 1,106 \\
\hline
\end{tabular}

Sumber: Data Diolah, 2018

Tabel 2 menunjukkan bahwa nilai konstanta (a) sebesar 18,659 dan koefisien regresi $\beta_{1}=0,464 ; \beta_{2}=-10,150 ; \beta_{3}=-3,518$; dan $\beta_{4}=-1,657$. Persamaan model regresi linier berganda berikut menunjukkan hubungan antara variabel independen dan variabel dependen.

$$
Y=18,659+0,464 X_{1}-10,150 X_{2}-3,518 X_{3}-1,657 X_{4}+\varepsilon
$$

Nilai konstanta $(\alpha)$ sebesar 18,659 menunjukkan bahwa jika nilai profitabilitas, kompleksitas operasi perusahaan, audit tenure, dan reputasi KAP nol, maka nilai kecepatan publikasi laporan keuangan sebesar 18,659 atau pembulatan menjadi 19 hari.

Koefisien regresi variabel profitabilitas $\left(\mathrm{X}_{1}\right)$ sebesar 0,464 menunjukkan apabila profitabilitas meningkat maka kecepatan publikasi laporan keuangan (Y) akan bertambah sebesar 0,464 dengan asumsi variabel lainnya konstan.

Koefisien regresi variabel kompleksitas operasi perusahaan $\left(\mathrm{X}_{2}\right)$ sebesar $-10,150$ menunjukkan apabila kompleksitas operasi perusahaan meningkat maka kecepatan publikasi laporan keuangan (Y) akan berkurang sebesar 10,150 dengan asumsi variabel lainnya konstan. 
Koefisien regresi variabel audit tenure $\left(\mathrm{X}_{3}\right)$ sebesar -3,518 menunjukkan apabila audit tenure meningkat maka kecepatan publikasi laporan keuangan (Y) akan berkurang sebesar 3,518 dengan asumsi variabel lainnya konstan.

Koefisien regresi variabel reputasi KAP $\left(\mathrm{X}_{4}\right)$ sebesar -1,657 menunjukkan apabila reputasi KAP meningkat maka kecepatan publikasi laporan keuangan (Y) akan berkurang sebesar 1,657 dengan asumsi variabel lainnya konstan.

Uji koefisien determinasi $\left(\mathrm{R}^{2}\right)$ menunjukkan bahwa nilai adjusted $\mathrm{R}$ Square sebesar 0,178 (17,8\%). Hal ini berarti 17,8\% variasi tingkat kecepatan publikasi laporan keuangan dapat dijelaskan oleh variabel profitabilitas, kompleksitas operasi perusahaan, audit tenure, dan reputasi KAP. Sisanya 82,2\% dijelaskan oleh faktor lain yang tidak disertakan dalam variabel penelitian ini.

Uji kelayakan model (Uji F) menunjukkan nilai signifikan F lebih kecil dari 0,05 yaitu 0,003 sehingga dapat disimpulkan bahwa model penelitian layak untuk digunakan sebagai model regresi dan menunjukkan secara simultan terdapat pengaruh yang signifikan antara variabel bebas yaitu profitabilitas, kompleksitas operasi perusahaan, audit tenure, dan reputasi KAP terhadap variabel terikat yaitu kecepatan publikasi laporan keuangan.

Uji statistik t pada dasarnya menunjukkan seberapa jauh pengaruh suatu variabel penjelas atau independen secara individu dalam menerangkan variasi variabel dependen. Tabel 4.10 berikut menampilkan hasil uji hipotesis. 
Tabel 3.

Hasil Uji Hipotesis (Uji t)

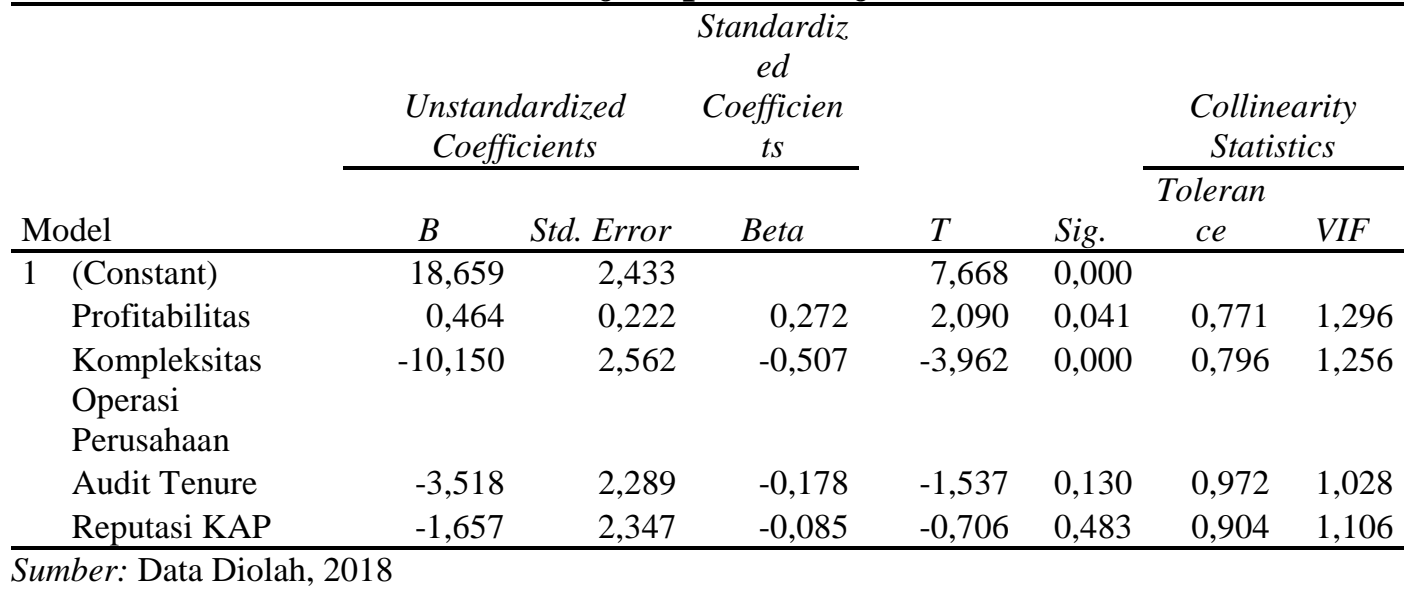

Tabel 3 menunjukkan bahwa nilai koefisien regresi variabel profitabilitas sebesar 0,464 dengan tingkat signifikansi sebesar 0,041 lebih kecil dari taraf signifikansi $(\alpha)$ sebesar 0,05 serta memiliki koefisien regresi yang bernilai positif sehingga $\mathrm{H}_{0}$ ditolak dan $\mathrm{H}_{1}$ diterima. Hasil ini menunjukkan bahwa variabel profitabilitas berpengaruh positif pada kecepatan publikasi laporan keuangan.

Profitabilitas adalah rasio keuangan yang biasanya digunakan untuk menggambarkan kemampuan suatu perusahaan dalam menghasilkan keuntungan (laba) memakai seluruh modal yang dimiliki perusahaan. Perusahaan yang mengalami kenaikan tingkat laba akan mengumumkan lebih cepat laporan keuangannya, sehingga akan memberikan respon positif pada kinerja perusahaannya. Semakin besar rasio profitabilitas maka semakin baik pula kinerja perusahaan dalam menghasilkan laba, sehingga perusahaan akan cenderung untuk memberikan informasi tersebut kepada pihak lain yang berkepentingan dengan lebih cepat (Rambe et al., 2017).

Hasil penelitian ini mampu mendukung adanya teori keagenan. Vuran dan Adiloglu (2013) berpendapat bahwa ketepatan waktu memiliki hubungan dengan 
profitabilitas dengan variabel Return On Asset (ROA) dala teori keagenan (agency theory) melalui bonus plan hypothesis. Perusahaan yang mengalami kenaikan tingkat laba akan mengumumkan lebih cepat laporan keuangannya, sehingga akan memberikan respon positif pada kinerja perusahaannya.

Tabel 3 menunjukkan bahwa nilai koefisien regresi variabel kompleksitas operasi perusahaan sebesar $-10,150$ dengan tingkat signifikansi sebesar 0,000 lebih kecil dari taraf signifikansi $(\alpha)$ sebesar 0,05 serta memiliki koefisien regresi yang bernilai negatif sehingga $\mathrm{H}_{0}$ ditolak dan $\mathrm{H}_{1}$ diterima. Hasil ini menunjukkan bahwa variabel kompleksitas operasi perusahaan berpengaruh negatif pada kecepatan publikasi laporan keuangan.

Hasil ini mendukung penelitian yang dilakukan oleh Pradana (2013), Widyastuti \& Astika (2017), dan Rusmin \& Evans (2017) menyatakan semakin kompleks operasi suatu perusahaan maka akan semakin panjang waktu penyelesaian audit, sehingga semakin lambat perusahaan dalam mempublikasikan laporan keuangannya. Tingkat kompleksitas operasi suatu perusahaan sangat tergantung pada kuantitas dan perusahaan anak serta keanekaragaman produk dan pasarnya. Kompleksitas operasi perusahaan dapat memperpanjang audit delay dikarenakan auditor akan memerlukan banyak waktu untuk mengaudit anak cabang dari perusahaan sebelum mengaudit induk perusahaannya dan juga meningkatkan biaya untuk mengaudit setiap anak cabang dari perusahaan (Ashton et al., 1987). Che-Ahmad \& Abidin (2008) menyatakan bahwa jumlah anak perusahaan yang dimiliki perusahaan mencerminkan bahwa perusahaan memiliki 
Ni Ketut Ressa Mahayani dan Made Gede Wirakusuma. Pengaruh ...

unit operasi yang lebih banyak yang harus diperiksa dalam setiap transaksi dan catatan yang menyertainya.

Penelitian ini sejalan dengan teori keagenan yang menjelaskan hubungan antara agen dengan prinsipal. Perusahaan yang dengan banyak perusahaan anak akan memiliki pelaporan keuangan kompleks yang dapat memunculkan asimetri informasi, sehingga dibutuhkan ketelitian dalam mengaudit laporan keuangan dan berdampak pada terlambatnya pempublikasian laporan keuangan.

Tabel 3 menunjukkan bahwa nilai koefisien regresi variabel audit tenure sebesar $-3,518$ dengan tingkat signifikansi sebesar 0,130 lebih besar dari taraf signifikansi $(\alpha)$ sebesar 0,05 serta memiliki koefisien regresi yang bernilai negatif sehingga $\mathrm{H}_{0}$ diterima dan $\mathrm{H}_{1}$ ditolak. Hasil ini menunjukkan bahwa variabel audit tenure tidak memiliki pengaruh pada kecepatan publikasi laporan keuangan.

Hasil penelitian ini mendukung penelitian yang dilakukan oleh Krisnanda \& Ratnadi (2017) menyatakan bahwa audit tenure tidak berpengaruh pada kecepatan publikasi laporan keuangan tahunan, dengan demikian lamanya sebuah perusahaan menjadi klien dalam sebuah KAP atau perusahaan yang sering mengganti-ganti KAP tidak akan memengaruhi perusahaan tersebut dalam mempublikasikan laporan keuangan tahunannya. Hasil tersebut didukung dengan penelitian Rustiarini \& Sugiarti (2013) yang menyatakan bahwa audit tenure tidak berpengaruh pada ketepatwaktuan publikasi laporan keuangan. Narayana \& Yadnyana (2017) menyatakan bahwa lamanya perikatan dengan KAP tidak meningkatkan fungsi kontrol terhadap perusahaan, berarti kontrak yang terjadi antara perusahaan dan auditor tidak efisien sehingga tidak dapat mewujudkan 
tujuan perusahaan yaitu laporan keuangan yang berkualitas yang disampaikan secara tepat waktu. Lamanya perusahaan menjadi klien suatu KAP tidak menjamin hasil audit atas laporan keuangan auditan akan dikeluarkan lebih cepat, sebaliknya bila suatu perusahaan baru menjadi klien suatu KAP tidak menjamin laporan keuangan auditan akan dikeluarkan lebih lama dibandingkan perusahaan lain yang juga menjadi klien KAP tersebut (Narayana \& Yadnyana, 2017).

Hasil penelitian ini belum mampu mendukung adanya teori keagenan. Lamanya perikatan yang dilakukan perusahaan dengan KAP tidak dapat meningkatkan fungsi kontrol yang dapat membantu prinsipal dalam mengawasi prilaku agen. Kontrak yang terjadi antara perusahaan dan KAP menjadi tidak efisien, sehingga perusahaan belum mampu untuk mempublikasikan laporan keuangannya dengan cepat. Perikatan audit yang lama dapat menumbuhkan ikatan atau kedekatan antara auditor dengan klien yang akan mengurangi independensi dalam melaporkan informasi keuangan yang sebenarnya. Objektivitas kantor akuntan publik untuk menghasilkan kualitas audit yang baik dapat terancam dari hubungan kerja yang lama antara KAP dengan perusahaan klien.

Tabel 3 menunjukkan bahwa nilai koefisien regresi variabel reputasi KAP sebesar -1,657 dengan tingkat signifikansi sebesar 0,483 lebih besar dari taraf signifikansi $(\alpha)$ sebesar 0,05 serta memiliki koefisien regresi yang bernilai negatif sehingga $\mathrm{H}_{0}$ diterima dan $\mathrm{H}_{1}$ ditolak. Hasil ini menunjukkan bahwa variabel reputasi KAP tidak memiliki pengaruh pada kecepatan publikasi laporan keuangan. 
Ni Ketut Ressa Mahayani dan Made Gede Wirakusuma. Pengaruh ...

Hasil ini menunjukkan bahwa variabel reputasi KAP tidak memiliki pengaruh pada kecepatan publikasi laporan keuangan atau dengan kata lain perusahaan yang menggunakan atau tidak menggunakan jasa KAP yang memiliki reputasi tidak memengaruhi semakin panjang atau pendek rentang waktu yang dibutuhkan perusahaan untuk mempublikasikan laporan keuangannya. Hasil penelitian ini mendukung penelitian yang dilakukan oleh Carbaja \& Yadnyana (2015) yang menyatakan bahwa reputasi auditor tidak berpengaruh terhadap rentang waktu pengumuman laporan keuangan tahunan.

Hasil penelitian ini belum mampu mendukung adanya teori keagenan. Manajer sebagai agen yang diberikan wewenang oleh prinsipal untuk mengelola perusahaan akan cenderung memilih KAP yang memiliki reputasi baik dalam menilai laporan keuangan perusahaan. KAP yang memiliki reputasi baik dinilai lebih efektif dalam mengaudit dan menghasilkan laporan audit yang sesuai dengan kewajaran laporan keuangan perusahaan. Namun, Reputasi KAP yang baik tidak menjamin suatu perusahaan menyampaikan laporan keuangan dengan cepat.

\section{SIMPULAN}

Penelitian ini bertujuan untuk membuktikan secara empiris pengaruh faktor internal perusahaan yaitu profitabilitas dan kompleksitas operasi perusahaan dan faktor eksternal perusahaan yaitu audit tenure dan reputasi KAP pada kecepatan publikasi laporan keuangan tahunan. Profitabilitas berpengaruh positif pada kecepatan publikasi laporan keuangan. Tingginya tingkat laba yang dimiliki perusahaan menandakan bahwa semakin tinggi profitabilitas. Perusahaan yang 
mengalami kenaikan tingkat laba akan mengumumkan lebih cepat laporan keuangannya, sehingga akan memberikan respon positif pada kinerja perusahaannya. Kompleksitas operasi perusahaan berpengaruh negatif pada kecepatan publikasi laporan keuangan. Tingkat kompleksitas operasi suatu perusahaan sangat tergantung pada kuantitas dan perusahaan anak serta keanekaragaman produk dan pasarnya. Semakin banyak perusahaan anak yang dimiliki maka akan mengakibatkan semakin lambat publikasi laporan keuangan. Audit tenure tidak berpengaruh pada kecepatan publikasi laporan keuangan. Perikatan yang lama antara KAP dengan perusahaan klien tidak menjamin perusahaan dapat dengan cepat mempublikasikan laporan keuangannya. Reputasi KAP tidak berpengaruh pada kecepatan publikasi laporan keuangan. Perusahaan yang diaudit oleh KAP yang bereputasi pada spesialisasi sektor industri barang konsumsi ataupun tidak bereputasi pada spesialisasi sektor industri barang konsumsi tidak menjamin perusahaan dapat mempublikasikan laporan keuangannya dengan cepat.

Penelitian selanjutnya disarankan menambahkan variabel bebas lain seperti faktor internal perusahaan yaitu likuiditas dan solvabilitas, sedangkan faktor eksternal perusahaan yaitu opini audit dan ukuran KAP sehingga dapat menyempurnakan penelitian ini. Memperpanjang periode sampel penelitian agar hasil penelitian selanjutnya dapat menunjukkan hasil yang lebih baik. Menambah sektor perusahaan yang tidak hanya terpaku pada satu sektor tertentu, sehingga dapat memperoleh hasil dari penelitian yang dapat digunakan secara lebih luas dan manfaatnya pun akan lebih bernilai bagi banyak pembaca. Pihak manajemen 
perusahaan diharapkan untuk lebih memerhatikan kecepatan publikasi laporan keuangan, sehingga dapat memberikan penilaian positif masyarakat pada kinerja perusahaan.

\section{REFERENSI}

Adebayo, P. A., \& Adebiyi, W. K. (2016). Effect of Firm Characteristics on The Timeliness of Corporate Financial Reporting: Evidence from Nigerian Deposit Money Banks. International Journal of Economics, Commerce and Management., IV(3), 369-381.

Anggreni, N. K. A. A., \& Latrini, M. Y. (2016). Pengaruh Audit Tenure pada Kecepatan Publikasi Laporan Keuangan Auditan dengan Spesialisasi Industri Auditor sebagai Pemoderasi. E-Jurnal Akuntansi Universitas Udayana, $15(2), 832-846$.

Armstrong, C. S., Guay, W. R., \& Weber, J. P. (2010). The Role of Information and Financial Reporting in Corporate Governance and Debt Contracting. Journal of Accounting and Economics, 50 (2-3), 179-234.

Ashton, R., Wilingham, J., \& Elliot, R. (1987). An Empirical Analysis of Audit Delay. Journal of Accounting Research, 25 (2), 275-291.

Carbaja, L. K. I. C., \& Yadnyana, I. K. (2015). Pengaruh Profitabilitas, Ukuran Perusahaan, Reputasi KAP, dan Pergantian Auditor Pada Ketidaktepatwaktuan Pelaporan Keuangan. E-Jurnal Akuntansi Universitas Udayana, 13(2), 615-624.

Che-Ahmad, A. \& Abidi, S.(2008). Audit Delay of Listed Companies: A Case of Malaysia. International Business Research, 1 (4).

Clatworthy, M. A., \& Peel, M. J. (2016). The Timeliness of UK Private Company Financial Reporting: Regulatory and Economic Influences. British Accounting Review, 48(3), 297-315. https://doi.org/10.1016/j.bar.2016.05.001

Darmansyah, R. K. \& Suratno. (2018). Peran Spesialisasi Industri Auditor Sebagai Pemoderasi Atas Pengaruh Audit Tenure dan Reputasi Kantor Akuntan Publik Pada Kualitas Audit. Jipi, 2(2), 53-68

Darmawan, Y. I. P., \& Widhiyani, N. L. S. (2017). Pengaruh Ukuran Perusahaan, Kompleksitas Operasi Perusahaan, dan Komite Audit pada Audit Delay. E- 
Jurnal Akuntansi Univeristas Udayana, 21(1), 254-282.

Dhao, M. \& Pham, T. (2014). Audit Tenure, Audit Specilization, and Audit Report Lag. Managerial Auditing Journal, 29 (6), 490-512.

Dyer, J.D. \& Hugh, A. M. (1975). The Timeliness of The Australian Annual Report. Journal of Accounting Research (Auntumn), 204-219.

Hossein, A. \& Zohreh, A. (2011). Relantionship Between Audit Industry Specialization and Audit Report lag in Companies Listed in Tehran Stock Exchange. Journal of Accounting Knowlegde, Auditing and Texation, 4 (14), 7-26.

Krisnanda, I. G. W., \& Ratnadi, N. M. D. (2017). Pengaruh Financial Distress, Umur Perusahaan, Audit Tenure, Kompetensi Dewan Komisaris Pada Kecepatan Publikasi Laporan Keungan. E-Jurnal Akuntansi Universitas Udayana, 20(3), 1933-1960.

Laksono, F. D., \& Mu'id, D. (2014). Analisis Faktor-Faktor yang Mempengaruhi Audit Delay dan Ketepatan Waktu Publikasi Laporan Keuangan. Diponegoro Journal of Accounting, 3(4), 1-13.

Lee, H.Y., Viviek, \& Mungso, S. (2009). Do Lengthy Auditor Tenure and The Provision of Non-Audit Service by The Eksternal Auditor Reduce Audit Report Legs? International Journal of Auditing, 13 (2), 87-104.

Liu, C. L., \& Lai, S. M. (2012). Organizational Complexity and Auditor Quality. Corporate Governance: An International Review, 20(4), 352-368. https://doi.org/10.1111/j.1467-8683.2012.00914.x

Mardyana, R. (2014). Effect of Good Corporate Governance, Financial Distress, and Financial Performance on Timeliness Of Financial Statements Reporting. International Program in Accounting, Economics Business Faculty, 1(3), 1-25.

Narayana, D. G. A., \& Yadnyana, I. K. (2017). Pengaruh Struktur Kepemilikan, Financial Distress dan Audit Tenure Pada Ketepatwaktuan Publikasi Laporan Keuangan. E-Jurnal Akuntansi Universitas Udayana, 18(3), 2085-2114.

Panjaitan, Z. F., Wahidahwati, \& Amanah, L. (2013). Faktor-Faktor Yang Mempengaruhi Audit Delay dan Timeliness Atas Penyampaian Laporan Keuangan. Jurnal Ilmu \& Riset Akuntansi, 2(11).

Pradana, M. N. R. \& Wirakusuma, M. G. (2013). Pengaruh Faktor-Faktor Non Finansial Pada Keterlambatan Publikasi Laporan Keuangan Tahunan Perusahaan. E-Jurnal Akuntansi Universitas Udayana, 3 (2), 277-296. 
Pradipta, D. N., \& Suryono, B. (2017). Analisis Faktor-Faktor yang Mempengaruhi Ketepatan Waktu Pelaporan Keuangan. Jurnal Ilmu Dan Riset Akuntansi, 6(3), 1200-1216.

Primantara, I. M., \& Rasmini, N. K. (2015). Pengaruh Jenis Industri,Spesialisasi Industri Auditor,dan Opini Auditor pada Audit Delay. E-Jurnal Akuntansi Universitas Udayana, 13(3), 1001-1028.

Rambe, P. A., Ruwati, S., \& Sari, I. M. (2017). Faktor-Faktor yang Mempengaruhi Kecepatan Penyampaian Laporan Keuangan Pada Perusahaan Manufaktur yang Terdaftar di Bursa Efek Indonesia Periode 2013-2016. Jurnal Fakultas Ekonomi Universitas Maritim Raja Ali Haji, 126.

Rustiarini, N. W. \& Sugiarti, N. W. M. (2013). Pengaruh Karakteristik Auditor, Opini Audit, Audit Tenure, Pergantian Auditor pada Audit Delay. Jurnal Ilmiah Akuntansi dan Humanika, 2 (2), 657-675.

Rusmin, R. \& Evans, J. (2017). Audit Quality \& Audit Report Lag: Case of Indonesian Listed Companies. Asian Review of Accounting, 25 (2), 191-210.

Sawitri, N. M. D. C., \& Budiartha, I. K. (2018). Pengaruh Audit Tenure dan Financial Distress pada Audit Delay dengan Spesialisasi Auditor Sebagai Variabel Pemoderasi. E-Jurnal Akuntansi Universitas Udayana, 22(3), 1965-1991. https://doi.org/https://doi.org/10.24843/EJA.2018.v22.i03.p12

Senjaya, K., \& Suprasto H, B. (2016). Tingkat Spesialisasi Industri Auditor sebagai Pemoderasi Pengaruh Ukuran Perusahaan Pada Audit Delay. EJurnal Akuntansi Universitas Udayana, 14(3), 2013-2040. https://doi.org/10.4135/9781452275147.n9

Skinner, D. J., \& Srinivasan, S. (2012). Audit Quality and Auditor Reputation: Evidence from Japan. The Accounting Review, 87(5), 1737-1765.

Van Johnson, E., Khurana, I. K., \& Reynolds, J. K. 2002. Audit-Firm Tenure and the Quality of Financial Reports. Contemporary Accounting Research, 19(4), 637-660.

Vuran, B. \& Adiloglu, B. (2013). Is Timeliness of Corporate Financial Reporting Related to Accounting Variables? Evidence From Istanbul Stock Exchange. International Journal of Business and Social Science, 4 (6).

Widyastuti, M. T., \& Astika, I. B. P. (2017). Pengaruh Ukuran Perusahaan, Kompleksitas Operasi Perusahaan dan Jenis Industri terhadap Audit Delay. E-Jurnal Akuntansi Universitas Udayana, 18(5), 1082-1111. 